\title{
Effect of drying treatments on warping of 36-year-old white spruce seed sources tested in a provenance trial
}

\author{
Jean Beaulieu ${ }^{\mathrm{a} *}$, Bruno Girard ${ }^{\mathrm{a}, \mathrm{b}}$ and Yves Fortin ${ }^{\mathrm{b}}$ \\ ${ }^{a}$ Natural Resources Canada, Canadian Forest Service, Laurentian Forestry Centre, 1055 du PEPS, P.O. Box 3800, Sainte-Foy, Quebec G1V 4C7, Canada \\ ${ }^{\mathrm{b}}$ Faculté de foresterie et géomatique, Université Laval, Sainte-Foy, Québec G1K 7P4, Canada
}

(Received 5 July 2001; accepted 31 January 2002)

\begin{abstract}
Wood from plantations will increasingly become a major source of supply for the lumber industry and this raw material is likely to have characteristics much different from those of the wood harvested in natural forests. This could require costly adjustments to manufacturing processes to maintain the quality of the end-use products. In Canada, white spruce (Picea glauca [Moench] Voss) is one of the main reforestation species and one of the most extensively used for lumber. In this study we investigated the genetic variation in warping in kiln drying of 25 white spruce provenances grown in a plantation and one from a second-growth forest stand. All of them were from the Great Lakes - St. Lawrence region. Two drying treatments were applied, i.e. conventional and high-temperature drying. For bow, crook and twist warp defects after drying, significant differences were not found among the provenances tested, nor between the drying treatments. However, significant differences were revealed between the mean of all provenances (plantation-grown) and wood from second-growth forests for crook and twist defects. The high proportion of tree to tree variation provides grounds for hope of rapid gains through mass selection.
\end{abstract}

kiln drying / bow / crook / twist / plantation

Résumé - Effets du procédé de séchage sur le gauchissement du bois d'épinette blanche issu d'une plantation de 36 ans. Le bois produit et récolté dans des plantations est appelé à devenir une source d'approvisionnement de plus en plus importante pour l'industrie forestière, et ce bois est susceptible de posséder des propriétés différentes de celles du bois récolté en forêt naturelle. Ceci pourrait ainsi engendrer des ajustements coûteux aux processus manufacturiers pour maintenir la qualité des produits finis. Au Canada, l'épinette blanche (Picea glauca [Moench] Voss) est une des principales essences forestières utilisées pour le reboisement, et pour la production de bois de sciage. Dans cette étude, nous avons examiné la variation génétique du gauchissement après séchage de 25 provenances de bois de colombage ainsi qu'un échantillon de forêt de seconde venue. Toutes les provenances provenaient de la région des Grands-Lacs et du Saint-Laurent. Deux traitements de séchage ont été testés, c'est-à-dire le séchage conventionnel et le séchage à haute température. Nous n'avons pas trouvé de différences significatives entre les deux traitements, non plus entre les provenances pour la voilure, la cambrure ou la torsion. Des différences significatives ont toutefois été trouvées entre la moyenne des provenances (plantation) et celle des échantillons recueillis dans une forêt de seconde venue, et ce pour la cambrure et la torsion. L'importance de la variation existant d'un arbre à l'autre laisse présager la possibilité de réaliser des gains génétiques via la sélection massique.

séchage au séchoir / voilure / cambrure / torsion / plantation

\section{INTRODUCTION}

White spruce (Picea glauca (Moench) Voss) is one of the most common conifers in Canada [11]. It has a transcontinental range, from Newfoundland and Labrador west across Canada along the northern tree line to the Northwest Territories and the Yukon. It is found in all forested regions of the country except on the Pacific coast. In the United States, it grows in Alaska, where it reaches the Bering Sea, in northern
Minnesota and Wisconsin, and in northeastern New York and Maine [24]. It is a medium-sized tree growing from sea level to $1500 \mathrm{~m}$ in a variety of climatic conditions and soils. Exceptionally large trees have also been reported in the past with a height of over $55 \mathrm{~m}$ and a diameter at breast height of $1.2 \mathrm{~m}$ [30]. In eastern Canada, it is generally found in mixed stands associated with black spruce (Picea mariana (Mill.) BSP), red spruce (Picea rubens Sarg.), trembling aspen (Populus tremuloides Michx.), white birch (Betula papyrifera Marsh.)

\footnotetext{
* Correspondence and reprints

Tel.: 418648 5823; fax: 418648 5849; e-mail: beaulieu@cfl.forestry.ca
} 
and balsam fir (Abies balsamea (L.) Mill.). It also forms pure stands but mainly in maritime regions.

Given its wide ecological amplitude, white spruce is expected to harbour extended intraspecific genetic variation [23]. This species is also shaped by introgressive hybridization which occurs with Sitka spruce (Picea sitchensis (Bong.) Carrière) as well as with Engelmann spruce (Picea engelmannii Parry ex Engelm.) in western Canada [27]. This introgression between the latter and white spruce is so extended that it creates a species complex known as interior spruce [19]. However, introgressive hybridization between white spruce and other congeneric species is infrequent in eastern Canada. A natural hybrid between white and black spruce has been reported only once [26], but artificial hybrids have been produced [33].

Genetic variation has been studied for various characters in white spruce. Hence, for biochemical markers such as isoenzymes and DNA markers, it was not possible to detect significant differences among populations, either at a regional scale [1, 5, 17], or at the range-wide scale [12]. Even though there is still controversy about that, genetic variation at the molecular level is believed to be essentially selectively neutral. For quantitative traits, the picture is quite different. For instance, it has been shown that based on monoterpene composition, white spruce west of Ontario was different from that growing in the east [32]. For height and phenological characters, contradictory results were reported with highly significant differences among provenances in some instances $[12,17,20]$, and the absence of such differences in other cases $[10,25]$. Provenances from southeastern Ontario and southwestern Quebec were reported to be among the best for growth in most of the provenance trials set up in eastern Canada and the northeastern United States [6, 23]. Differences between provenances growing on limestone and granitic soils were also reported [31]. Genetic variation was also analyzed for wood density. It was shown to be under strong genetic control $[9,34]$, and significant differences among provenances were also reported $[2,7,8]$. Although wood density is considered to provide excellent means to predict some end-use characteristics of wood [18], there is a need to study genetic variation directly at the end-use product level. Indeed, the quality of end products is not only affected by mean density and its variation, but also by other anatomical characteristics such as the spiral grain observed in juvenile wood. Hence, more direct data on wood processing behaviour and mechanical properties are needed, especially when trees are grown in plantations. Very few studies on wood properties in plantation-grown white spruce have been carried out so far $[15,35,36]$, and in the coming years, the wood processing industry will have to deal with new problems caused by the increasing amount of this new raw material. Indeed, white spruce, being one of the most important species for pulp and lumber, is also one of the major species for reforestation in Canada. More than 150000 ha are planted yearly with spruce species in Canada [3], and probably at least half of that is white spruce. The proportion of juvenile wood is expected to increase in plantation-grown stock mainly due to shortened rotations. With juvenile wood making up a large portion of wood in the logs, warp defects could increase after lumber is dried [29].

The objectives of this study were (1) to estimate the effect of conventional and high-temperature drying with top-load restraint on the warping of white spruce lumber, and (2) to provide the lumber industry with recommendations regarding kiln drying of white spruce lumber harvested from plantations.

\section{MATERIALS AND METHODS}

\subsection{Materials}

In the spring of 1964, 4-year-old seedlings raised at the Petawawa National Forestry Institute (Lat. $45^{\circ} 59^{\prime} \mathrm{N}$, Long. $77^{\circ} 24^{\prime} \mathrm{W}$ ) were used to establish a provenance trial at the Harrington Forest Farm (Lat. $45^{\circ} 48^{\prime} \mathrm{N}$, Long. $74^{\circ} 38^{\prime} \mathrm{W}$ ). The seedlings were from 25 provenances sampled in the Great Lakes - St. Lawrence region ( $f$ igure 1). Spacing was $1.8 \mathrm{~m} \times 1.8 \mathrm{~m}$. The experimental design was a randomized complete block design, with each provenance represented by a $6 \times 6$ square plot. In 1984, trees were pruned at a height of $2 \mathrm{~m}$, and 12 years later, i.e. in the fall of 1996, the provenance trial (figure 2) was thinned with a feller/delimber. Six trees from each provenance, having a diameter of at least $17 \mathrm{~cm}$ at a height of $5 \mathrm{~m}$, were retained for this study. Whenever possible, the six trees were taken from the first block. For a few provenances, trees coming from the second block were used to complete the test material. The average diameter below bark at stump level was about $25 \mathrm{~cm}$ with values ranging from 20.5 to $36.5 \mathrm{~cm}$.

Each tree was first cross cut into 2.5-m-long logs. Only the first two logs were kept for this study. These were processed directly on site into three rough-sawn $2 \times 4$ studs $(5 \mathrm{~cm} \times 10 \mathrm{~cm})$ using a portable band sawmill. The log was first squared on three faces and then ripsawn so that the middle piece was boxed-pith and the two other pieces contained mostly sapwood. Each board was labelled with an aluminum tag identifying the provenance, the tree and the position of the $\log$ (butt or second) in the stem. The lumber was solid piled, wrapped in plastic film and transported to Université Laval to be stored at $-20{ }^{\circ} \mathrm{C}$ until further processing. Six more trees were harvested from a second-growth natural stand at the Valcartier Forest Experiment Station near Quebec City (Lat. $46^{\circ} 56^{\prime}$ N, Long. $71^{\circ} 28^{\prime} \mathrm{W}$ ). The trees were about 40 years old. They were processed into $2 \times 4$ 's in the same way as for the trees from the provenance trial and were used as a forest-grown standard for data analysis.

\subsection{Methods}

The lumber was dried to a final moisture content (FMC) of $10 \%$ in an experimental kiln of $2.5 \mathrm{~m}^{3}$ capacity at Université Laval. Two treatments were applied, i.e. conventional drying and high-temperature drying. The drying schedules were based on commercially developed schedules for white spruce dimension stock [4] and adapted to the drying of value-added products (target FMC of 10\%). A complete description of the treatments is provided in [13]. Each treatment was replicated three times. Hence, before being submitted to the treatments, the lumber was first divided into six groups, with the 


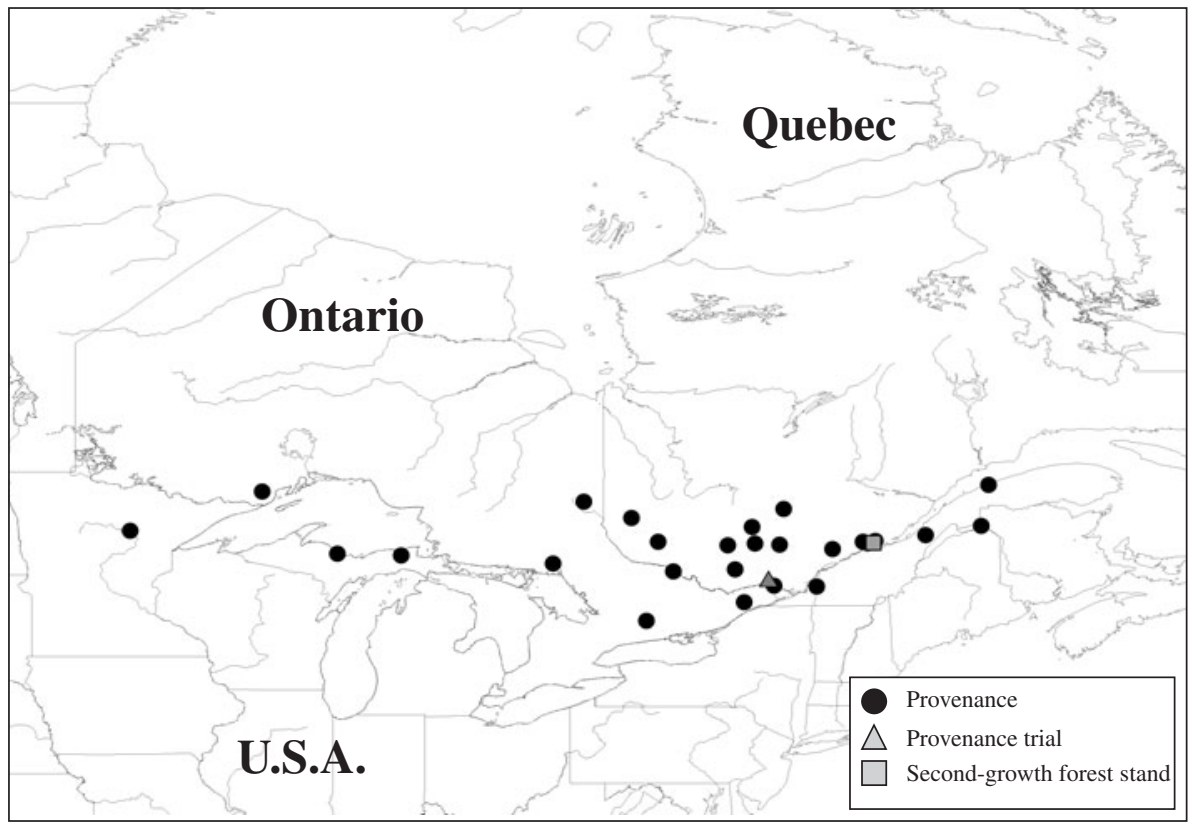

Figure 1. Location of the provenance trial, the second-growth forest stand and the provenances tested in the provenance trial.

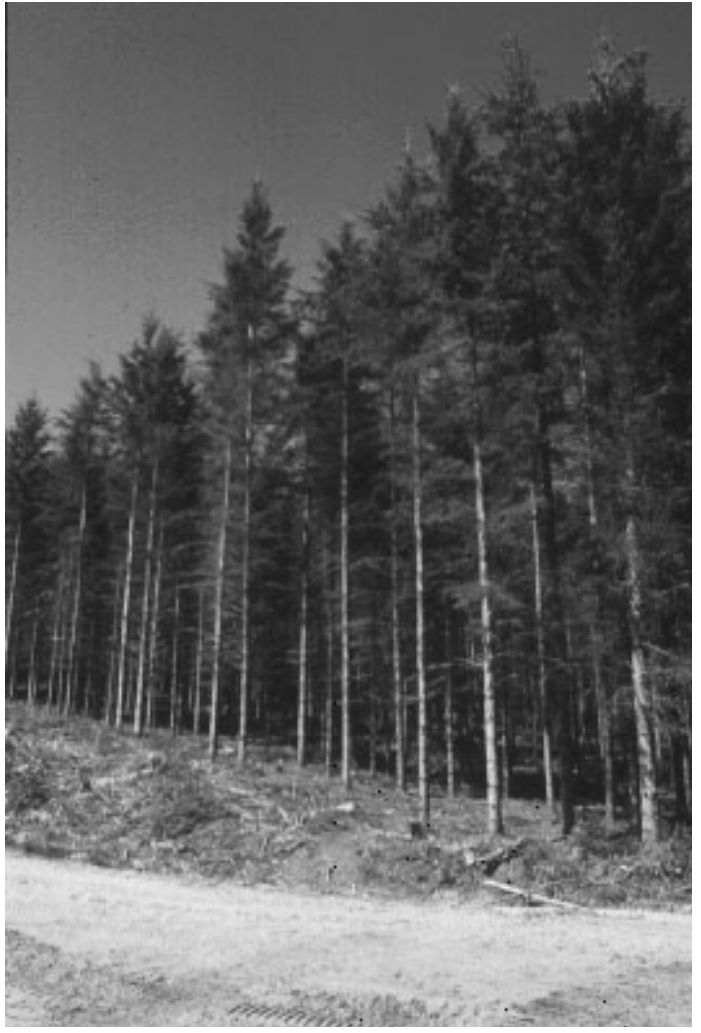

Figure 2. White spruce provenance trial located at the Harrington Forest Farm, in Quebec.

six boards from the same tree belonging to the same group. Due to the loss of identification for some material in the logging-sawing process, only 24 of the 26 provenances (including the forest-grown standard) were present in each of the six groups except for one which contained 25 provenances. Three groups among the six available were randomly selected and used as replicates for conventional drying while the three others were submitted to high-temperature drying. Because of the variation in lumber thickness due to the use of a portable sawmill, the lumber was presurfaced on both wide faces to a thickness of $41.5 \mathrm{~mm}$ just prior to drying. A top-load restraint of $7.2 \mathrm{~kg} \mathrm{~m}^{-2}\left(150 \mathrm{lb} \mathrm{ft}^{-2}\right)$ was applied in each drying run.

Various measurements were performed on each of the 144 to 150 pieces of the kiln load. Final weight $( \pm 1 \mathrm{~g})$, length $( \pm 1 \mathrm{~mm})$, thickness and width $( \pm 0.01 \mathrm{~mm})$ were collected immediately after drying. Width and thickness measurements were taken at a distance of $0.6 \mathrm{~m}$ from both ends. Bow and crook were measured to the nearest $1 \mathrm{~mm}$ at the points of maximum deviation by placing the stud (flatwise for bow and edgewise for crook) on a long plane table (wide-flange steel beam). Twist was ascertained by holding three corners of the stud down on the beam surface and measuring the distance from the surface to the other corner of the piece. Nominal relative density (oven-dry weight / volume at FMC) of each stud was determined, the oven-dry weight being estimated from the final weight and the FMC obtained from a resistance-type moisture meter.

\subsection{Data analysis}

Warp data were analyzed using the following mixed model:

$$
\begin{gathered}
\mathrm{Y}_{\mathrm{ijklm}}=\mu+\tau_{\mathrm{i}}+\mathrm{r}_{\mathrm{ij}}+\rho_{\mathrm{k}}+(\tau \rho)_{\mathrm{ik}}+\mathrm{s}_{\mathrm{ijk}}+\lambda_{1}+(\tau \lambda)_{\mathrm{il}}+\mathrm{t}_{\mathrm{ij} l} \\
+(\rho \lambda)_{\mathrm{kl}}+(\tau \rho \lambda)_{\mathrm{ikl}}+\mathrm{u}_{\mathrm{ijkl}}+\mathrm{e}_{\mathrm{ijkl} \mathrm{m}},
\end{gathered}
$$

where:

$\mathrm{Y}_{\mathrm{ijklm}}$ is the trait measured on the $\mathrm{m}$-th stud from the $\log$ in position 1 in the tree representing provenance $\mathrm{k}$ submitted to treatment $\mathrm{i}$ in $\operatorname{run} \mathrm{j}$;

$\mu$ is an overall effect;

$\tau_{\mathrm{i}}$ is the effect of $\mathrm{i}$-th treatment (conventional or high-temperature kiln drying) $(i=1,2)$; 
Table I. Observed significance $\left(P>\mathrm{F}^{1}\right)$ associated with the analysis of variance of warp variables collected on white spruce $2 \times 4$ studs.

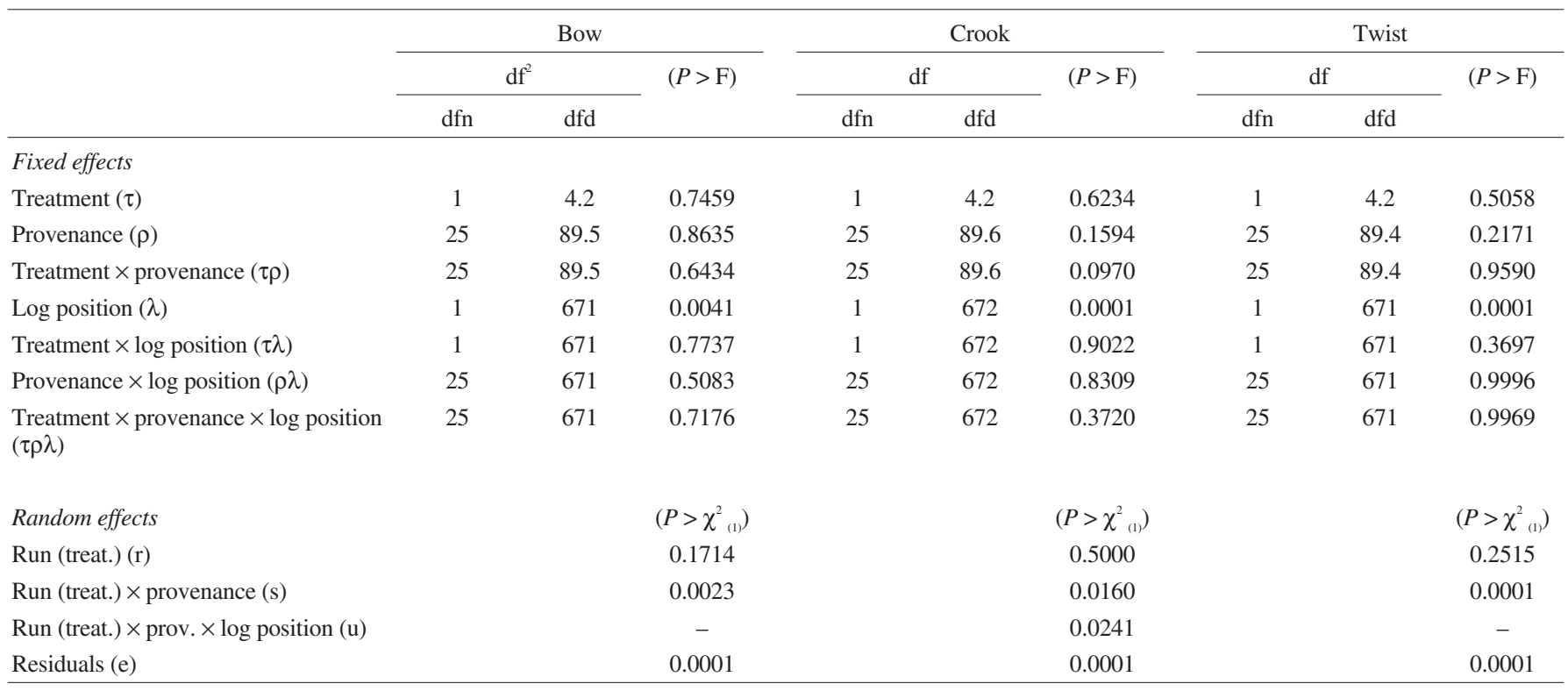

Significant at $\alpha=0.05$ after Bonferroni correction when $P<0.0167(0.05 / 3)$.

df, degrees of freedom; dfn, degrees of freedom of the numerator; dfd, degrees of freedom of the denominator.

$r_{i j}$ is the random effect of the $\mathrm{j}$-th run within the i-th drying technique; it is assumed that $\mathrm{r}_{\mathrm{ij}}$ is an observation from a normal distribution with mean zero and variance $s_{r}^{2}(j=1,2,3)$;

$\rho_{\mathrm{k}}$ is the effect of the $\mathrm{k}$-th provenance $(\mathrm{k}=1, \ldots, 26)$;

$(\tau \rho)_{\mathrm{ik}}$ is the effect of the interaction between the i-th drying technique and the $\mathrm{k}$-th provenance;

$\mathrm{s}_{\mathrm{ijk}}$ is the random tree effect; it is assumed that $\mathrm{s}_{\mathrm{ijk}} \sim \mathrm{N}\left(0, \sigma_{\mathrm{s}}^{2}\right)$;

$\lambda_{1}$ is the effect of the 1-th $\log$ position (first or second log of the stem, $1=1,2)$;

$(\tau \lambda)_{\mathrm{il}}$ is the effect of the interaction between the i-th drying technique and the 1-th log position;

$t_{i j 1}$ is the random effect of the group of logs in the 1-th position for all provenances in the $\mathrm{j}$-th run within the $\mathrm{i}$-th drying technique; it is assumed that $\mathrm{t}_{\mathrm{ij} 1} \sim \mathrm{N}\left(0, \sigma_{\mathrm{t}}^{2}\right)$;

$(\rho \lambda)_{\mathrm{kl}}$ is the effect of the interaction between the $\mathrm{k}$-th provenance and the 1-th log position;

$(\tau \rho \lambda)_{\mathrm{ikl}}$ is the effect of the interaction between the i-th drying technique, the $\mathrm{k}$-th provenance and the 1 -th log position;

$\mathrm{u}_{\mathrm{ijkl}}$ is the random effect of the log in the l-th position from the k-th provenance in the $\mathrm{j}$-th run within the $\mathrm{i}$-th drying technique; it is assumed that $\mathrm{u}_{\mathrm{ijkl}} \sim \mathrm{N}\left(0, \sigma^{2}{ }_{\mathrm{u}}\right)$;

and $\mathrm{e}_{\mathrm{ijklm}}$ is a random error term associated with the $\mathrm{m}$-th stud from the $\log$ in 1-th position of the trees of the $\mathrm{k}$-th provenance, in the $\mathrm{j}$-th run within the $\mathrm{i}$-th drying technique; it is assumed that $\mathrm{e}_{\mathrm{ijk} \mathrm{km}} \sim \mathrm{N}(0$, $\sigma_{\mathrm{e}}^{2}$ ).

The model was reduced to its most parsimonious form by testing successively for the significance of each variance component, starting with $\sigma^{2}{ }_{u}$ and ending with $\sigma_{r}^{2}$. If, based on a likelihood ratio statistic test, a given random effect was not significant at 0.30 , it was excluded from the model as recommended by [22]. On the contrary, it was not excluded from the model and the reduction process was carried on with other random effects not yet tested. The analyses of variance were performed using the MIXED procedure [21, 28]. Correlation analysis (Proc CORR [28]) was performed among all the warp defects and the nominal relative density in order to show the relationships existing among warp defects and the effect of wood density on them.

\section{RESULTS AND DISCUSSION}

Results of the analyses of variance performed on data did not show significant differences between the two drying treatments for the three warp defects studied (table I). Thus, the main results were presented by pooling the values of the drying treatments (see table II). The overall average deformation for the plantation-grown wood (25 provenances) were $4.2 \mathrm{~mm}, 1.0 \mathrm{~mm}$ and $5.9 \mathrm{~mm}$, for bow, crook and twist, respectively. There were no significant differences among the provenances for any of the warp defects. The absence of significant differences among provenances was unanticipated because such variation in white spruce had already been reported for other traits including growth and wood density [2, 20, 23]. Furthermore, these traits are known to affect the quality of end-use products [38]. However, the use of top-load restraint for both drying treatments may have contributed to the uniformity of drying quality among provenances. The absence of differences among provenances is an indication that end-use quality traits such as straightness after drying could not be improved by selecting superior provenances. No significant differences were observed on the same material for wood machining properties either [14]. That does not preclude the presence of differences among families and genotypes within families. Indeed, for many forest tree species, most of the variation is within provenances or 
Table II. Mean warp values after drying for 25 white spruce provenances and a second-growth forest. Warp measurements were taken on six $2 \times 4$ 's extracted from two logs in each tree.

\begin{tabular}{|c|c|c|c|c|c|c|}
\hline \multirow[t]{3}{*}{ Provenance identification } & \multicolumn{6}{|c|}{ Warp (mm) } \\
\hline & \multicolumn{2}{|c|}{ Bow } & \multicolumn{2}{|c|}{ Crook } & \multicolumn{2}{|c|}{ Twist } \\
\hline & $\log 1$ & $\log 2$ & $\log 1$ & $\log 2$ & $\log 1$ & $\log 2$ \\
\hline Peterborough, ON & 3.5 & 3.1 & 1.3 & 0.3 & 7.0 & 7.7 \\
\hline Winchester, ON & 4.8 & 3.7 & 1.8 & 0.7 & 4.3 & 5.9 \\
\hline Cushing, QC & 3.3 & 4.9 & 1.5 & 0.8 & 5.3 & 7.4 \\
\hline Belœil, QC & 4.8 & 5.4 & 1.8 & 0.4 & 6.3 & 6.9 \\
\hline Grandes Piles, QC & 4.2 & 3.8 & 0.8 & 0.4 & 5.3 & 5.9 \\
\hline St-Raymond, QC & 5.6 & 3.9 & 1.9 & 1.9 & 4.2 & 6.5 \\
\hline Casey, QC & 5.4 & 4.5 & 1.3 & 0.1 & 5.5 & 6.4 \\
\hline Lac Mattawin, QC & 5.2 & 3.0 & 0.4 & 0.5 & 5.9 & 7.6 \\
\hline Canton Franchère, QC & 3.1 & 4.1 & 1.4 & 0.8 & 7.4 & 7.2 \\
\hline Reservoir Baskatong, QC & 3.3 & 2.6 & 1.8 & 0.7 & 7.3 & 8.7 \\
\hline Lac Dumoine, QC & 4.1 & 3.2 & 1.8 & 1.4 & 5.7 & 6.9 \\
\hline Notre-Dame-du-Laus, QC & 4.7 & 3.7 & 1.1 & 0.9 & 3.8 & 5.2 \\
\hline Chalk River, ON & 5.5 & 3.6 & 1.9 & 0.5 & 4.8 & 6.0 \\
\hline Miller Lake, ON & 5.8 & 3.8 & 0.8 & 0.2 & 5.9 & 7.3 \\
\hline Monk, QC & 4.0 & 3.8 & 3.1 & 1.7 & 5.5 & 6.6 \\
\hline Price, QC & 3.8 & 3.4 & 1.2 & 0.7 & 4.1 & 5.3 \\
\hline Edmundston, NB & 6.4 & 4.3 & 1.7 & 0.5 & 4.1 & 4.6 \\
\hline Kakabeka, ON & 4.9 & 1.8 & 0.9 & 1.0 & 4.9 & 5.2 \\
\hline Lac Mitchinamecus, QC & 3.4 & 4.3 & 0.4 & 0.5 & 6.0 & 6.8 \\
\hline Lac Simard, QC & 4.0 & 4.9 & 0.8 & 0.5 & 6.4 & 6.2 \\
\hline Swastika, ON & 5.1 & 3.7 & 0.8 & 0.9 & 5.0 & 6.4 \\
\hline Valcartier, QC & 4.8 & 3.8 & 1.0 & 0.2 & 2.2 & 4.8 \\
\hline Grand Rapids, MN & 3.3 & 3.6 & 1.0 & 0.9 & 5.3 & 5.5 \\
\hline Luce, MI & 3.5 & 4.3 & 1.7 & 0.8 & 5.3 & 5.7 \\
\hline Marquette, MI & 5.7 & 5.2 & 0.6 & 0.2 & 6.4 & 7.0 \\
\hline Second-growth forest & 5.6 & 4.8 & 1.8 & 2.3 & 3.4 & 3.9 \\
\hline Plantation mean & 4.5 & 3.9 & 1.3 & 0.8 & 5.9 & 6.3 \\
\hline Standard error & \multicolumn{2}{|c|}{0.24} & \multicolumn{2}{|c|}{0.13} & \multicolumn{2}{|c|}{0.24} \\
\hline
\end{tabular}

populations, and this is the major source of variation that geneticists use in selection and breeding programs [37].

Wood from plantations is generally considered as having a higher proportion of juvenile wood [39]. Juvenile wood has properties such as the presence of spiral grain and/or high longitudinal shrinkage that tend to increase warping during the drying process [16]. Although warp deformation was on average relatively small, as all the provenance means met the NLGA warp standards for stud grade, there was considerable variation within and between provenances. Indeed, for bow, the provenance with the lowest value was Reservoir Baskatong, Quebec with $2.9 \mathrm{~mm}$, while the worst was Edmundston, New Brunswick with a bow of $5.4 \mathrm{~mm}$. Crook varied from $0.4 \mathrm{~mm}$, for Marquette, Michigan, to $2.4 \mathrm{~mm}$ for Monk, Quebec. Twist was the most significant defect with a range of $4.5 \mathrm{~mm}$, varying from $3.5 \mathrm{~mm}$ for Valcartier, Quebec to $8.0 \mathrm{~mm}$ for Reservoir Baskatong, Quebec.
A comparison between the forest-grown material and the average of the 25 provenances tested showed the existence of significant differences between both for crook and twist. Contrary to what was expected, the average crook in forest-grown material was higher than for the plantation-grown stock. However, the twist defect was on average $60 \%$ greater in plantation-grown wood. The wood from second-growth forest was represented by only six studs per run as compared with about 150 for the plantation-grown wood. The differences observed as well as the direction of these differences are likely to be highly influenced by the choice of the unique provenance representing the forest-grown material.

Interactions between the drying treatments and the provenances were not significant for any of the three types of warp. The only source of variation that was significant was the log position, and this is true for the three warp defects analyzed. Bow and crook were greater on average in the studs from the butt $\log$. The bow was $4.5 \mathrm{~mm}$ as compared with $3.9 \mathrm{~mm}$ (standard error $=0.24$ ), and the crook $1.3 \mathrm{~mm}$ as compared with $0.8 \mathrm{~mm}$ (standard error $=0.13$ ), for the butt $\log$ and the second $\log$, respectively. For twist, the trend was reversed in that the average warp deformation was $5.9 \mathrm{~mm}$ in the studs of the butt $\log$ and $6.3 \mathrm{~mm}$ in the studs of the second log (standard error $=0.24$ ). The significant differences are likely due to a varying proportion of mature and juvenile wood in both logs. The outer studs sawn from the butt log are expected to contain both juvenile and mature wood responding differentially to the drying stresses, while the ones coming from the second log probably had mostly juvenile wood, leading them to twist more.

Results of the correlation analysis showed that the three defects observed in a stud were not related to its nominal relative density (table III). However, twist was significantly related to the two other warp defects. Preliminary results of shrinkage [13] indicate that twist was significantly related to the shrinkage in width, thickness and longitude. Bow also seemed to be affected by longitudinal shrinkage and to a lesser extent by shrinkage in thickness, while crook was affected by both in width and longitudinal shrinkages. Hence, the interrelations between twist and the two others might be due to indirect relationships with shrinkage characteristics.

Results reported in this study showed that eastern white spruce plantation-grown wood has similar drying behaviour

Table III. Correlation coefficients (r) and $P$-values (second line) ${ }^{1}$ among warp defects and nominal relative density in white spruce.

\begin{tabular}{lccc}
\hline Trait & Crook & Twist & $\begin{array}{c}\text { Nominal relative } \\
\text { density }\end{array}$ \\
\hline Bow & 0.040 & -0.149 & 0.007 \\
Crook & $(0.2338)$ & $(0.0001)$ & $(0.8283)$ \\
& & 0.092 & -0.014 \\
Twist & & $(0.0068)$ & $(0.6778)$ \\
& & & -0.028 \\
\hline
\end{tabular}

${ }^{1}$ Significant at $\alpha=0.05$ after Bonferroni correction when $P<0.0083(0.05 / 6)$. 
whether it is submitted to conventional or high-temperature drying with top-load restraint. It was also shown that whatever the origin of the seed sources, the quality of end-use products was equivalent. This means that all the provenances responded globally the same way to the drying treatments. This is a positive result for the wood drying industry because it appears that no special adjustment will be needed for plantation wood based on the origin of the material. However, tree to tree variation exists, and concerns about plantation wood could be raised again in the future. Indeed, reforestation in eastern white spruce was done mostly with genetically unimproved stock in the past. Superior genotypes were selected mainly for growth and seed orchards were set up to produce genetically improved seed to meet all the reforestation needs. In the selection process, no attention was paid to wood quality traits. Seed orchards have begun to produce and the reforestation program is now largely supplied by seed collected in seed orchards. In order to respond to pressures for conserving a larger percentage of the land to protect biodiversity, there is a new trend toward increasing yield on the most fertile sites using clonal forestry for eastern white spruce. If wood quality traits, and especially end-use characteristics of wood, are not taken into account in the selection of the best clones, the lumber industry might be negatively affected in the future. The high proportion of tree to tree variation provides grounds for hope of rapid gains through mass selection. However, inheritance of these traits in white spruce is not known and would have first to be estimated to know the potential genetic gains. Moreover, genetic correlations between warping defects and other traits such as height, stem form and branch characteristics, already involved in the selection process of superior genotypes, would have to be evaluated to develop selection indices that include all these traits.

In this study, significant differences were found between the plantation-grown wood and that from the second-growth forest. While the sample size representing natural stands might not be large enough to state with confidence that plantation-grown wood is of lesser quality than wood harvested in natural stands, this result is a warning for the Canadian lumber industry. Further investigations are needed. Hence, a new study using a better balance between both types of material should be initiated as soon as possible.

Acknowledgments: The authors thank Fernand Robichaud, formerly of Bowater Paper Canada, for access to the material. They are also grateful to Jean-Paul Bilodeau, Roger Gagné, and the late Serge Légaré, of the Canadian Forest Service, Laurentian Forestry Centre, for their help with material processing. They also thank Michèle Bernier-Cardou for her advice on statistical analyses, Sylvain Boisclair for his help in data processing, Pamela Cheers for her editing work, and two anonymous reviewers for their constructive comments. This research was supported by Bowater Paper Canada, for the cost of the thinning operation of the provenance trial, a NSERC scholarship as well as a CFS supplementary grant to B. Girard, a grant to J. Beaulieu from the Forest Biotechnology Network of the Canadian Forest Service, and a Ministère des Ressouces naturelles du Québec grant to Y. Fortin.

\section{REFERENCES}

[1] Alden J., Loopstra C., Genetic diversity and population structure of $\mathrm{Pi}$ cea glauca on an altitudinal gradient in interior Alaska, Can. J. For. Res. 17 (1987) 1519-1526.

[2] Beaulieu J., Corriveau A., Variabilité de la densité du bois et de la production des provenances d'épinette blanche, 20 ans après plantation, Can. J. For. Res. 15 (1985) 833-838.

[3] Canadian Council of Forest Ministers, National Forestry Database Program, 1999. http: //nfdp.ccfm.org/

[4] Cech M.Y., Pfaff F., Dehumidification drying of spruce studs, For. Prod. J. 28 (1978) 22-26.

[5] Cheliak W.M., Murray G., Pitel J.A., Genetic effects of phenotypic selection in white spruce, For. Ecol. Manage. 24 (1988) 139-149.

[6] Corriveau A., Boudoux M., Le développement des provenances d'épinette blanche de la région forestière des Grands-Lacs et du St-Laurent au Québec, Serv. can. for., Lab. rech. for., 1971, Inf. Rep. QF-X-15.

[7] Corriveau A., Beaulieu J., Mothe F., Wood density of natural white spruce populations in Quebec, Can. J. For. Res. 17 (1987) 675-682.

[8] Corriveau A., Beaulieu J., Mothe F., Poliquin J., Doucet J., Densité et largeur des cernes des populations d'épinettes blanches de la région forestière des Grands Lacs et du St-Laurent, Can. J. For. Res. 20 (1990) 121-129.

[9] Corriveau A., Beaulieu J., Daoust G., Heritability and genetic correlations of wood characters of Upper Ottawa Valley white spruce populations grown in Quebec, For. Chron. 67 (1991) 698-705.

[10] Dhir N.K., Stand, family and site effects in Upper Ottawa Valley white spruce, in: Proc. 12th Lake States For. Tree Improv. Conf., Chalk River, Ont. August 1975, U.S. Dep. Agric. For. Serv. Gen. Tech. Rep. NC-26, 1976, pp. 88-97.

[11] Farrar J.L., Trees in Canada, Fitzhenry \& Whiteside Limited and Canadian Forest Service, Markham, 1995, 502 p.

[12] Furnier G.R., Stine M., Mohn C.A., Clyde M.A., Geographic patterns of variation in allozymes and height growth in white spruce, Can. J. For. Res. 21 (1991) 707-712.

[13] Girard B., Conventional and high-temperature drying treatments of white spruce wood from plantation forests. Master's thesis, Département des sciences du bois et de la forêt, Université Laval, Québec, 2001.

[14] Haslett A.N., Davy B., Dakin M., Bates R., Effect of pressure drying and pressure steaming on warp and stiffness of radiata pine lumber, For. Prod. J. 49 (1999) 67-71.

[15] Hernández R.E., Bustos C., Fortin Y., Beaulieu J., Wood machining properties of white spruce from plantation forests, For. Prod. J. 51 (2001) 82-88.

[16 ] Herzig L., Young modulus evaluation of white spruce by ultrasonic method on increment-cores. Master's thesis, Département des sciences du bois, Université Laval, Québec, 1991.

[17] Jaramillo-Correa J.P., Beaulieu J., Bousquet J., Contrasting evolutionary forces driving population structure at ESTPs, allozymes and quantitative traits in white spruce, Mol. Ecol. 10 (2001) 2729-2740.

[18] Jozsa L.A., Middleton G.R., A discussion of wood quality attributes and their practical implications, Forintek Canada Corp., Spec. Publ. No. SP-34, 1994, 42 p.

[19] Kiss G., Yeh F.C., Heritability estimates for height for young interior spruce in British Columbia, Can. J. For. Res. 18 (1987) 158-162.

[20] Li P., Beaulieu J., Bousquet J., Genetic structure and patterns of genetic variation among populations in eastern white spruce (Picea glauca), Can. J. For. Res. 27 (1997) 189-198.

[21] Littell R.C., Milliken G.E., Stroup W.W., Wolfinger R.D., SAS system for MIXED models, SAS Institute, Inc., Cary, NC, 1996, 633 p.

[22] Milliken G.A., Johnson D.E., The analysis of messy data. Vol. 1. Designed experiments, Van Nostrand Reinhold, New York, 1984, 473 p.

[23] Nienstaedt H., Teich A., The genetics of white spruce, U.S. For. Serv. Wash. Off., 1972, Res. Pap. WO-15.

[24] Nienstaedt H., Zasada J.C., Picea glauca (Moench) Voss, white spruce, in: Silvics of North America. Vol. 1. Conifers, Burns R.M., Honkala 
B.H. (Technical Coordinators), U.S. Dep. Agric. Agric. Handb. 654, 1990, pp. 204-226.

[25] Pollard D.F.W., Ying C.C., Variance in flushing among and within stands of seedling white spruce, Can. J. For. Res. 9 (1979) 517-521.

[26] Riemenschneider D., Mohn C.A., Chromatographic analysis of an open-pollinated Rosendahl spruce progeny, Can. J. For. Res. 5 (1975) 414-418.

[27] Roche L., A genecological study of the genus Picea in British Columbia, New Phytol. 68 (1969) 505-554.

[28] SAS Institute, Inc. SAS/STAT ${ }^{\oplus}$ User's Guide, Release 6, 4th ed., Cary, NC, 1997.

[29] Shelly J.R., Arganbright D.G., Birnbach M., Severe warp development in young-growth ponderosa pine studs, Wood Fiber Sci. 11 (1979) $50-56$.

[30] Sutton R.F., Silvics of white spruce [Picea glauca (Moench) Voss], Dep. Fish. For. Can. For. Branch, 1969, Publ. No. 1250.

[31] Teich A.H., Holst M.J., White spruce limestone ecotypes, For. Chron. 50 (1974) 110-111.
[32] Wilkinson R.C., Hanover J.W., Wright J.W., Flake R.H., Genetic variation in the monoterpene composition of white spruce, For. Sci. 17 (1971) 83-90.

[33] Wright J.W., Species crossability in spruce in relation to distribution and taxonomy, For. Sci. 1 (1955) 319-349.

[34] Yanchuk A.D., Kiss G.K., Genetic variation in growth and wood specific gravity and its utility in the improvement of interior spruce in British Columbia, Silvae Genet. 42 (1993) 141-148.

[35] Zhou H., Smith I., Influences of drying treatments on bending properties of plantation-grown white spruce, For. Prod. J. 41 (1991) 8-14.

[36] Zhou H., Smith I., Factors influencing bending properties of white spruce lumber, Wood Fiber Sci. 23 (1991) 483-500.

[37] Zobel B., Talbert J., Applied forest tree improvement, John Wiley \& Sons, New York, 1984, 505 p.

[38] Zobel B.J., van Buijtenen J.P., Wood variation: its causes and control, Springer-Verlag, Berlin, 1989, 363 p.

[39] Zobel B.J., Sprague J.R., Juvenile wood in forest trees, Springer-Verlag, Berlin, 1998, 300 p.

To access this journal online: www.edpsciences.org 
